\title{
Neurotoxicity in lymphoblastic leukaemia: comparison of oral and intramuscular methotrexate and two doses of radiation
}

\author{
J M Chessells, T C S Cox, B Kendall, N P C Cavanagh, L Jannoun, S Richards
}

\begin{abstract}
Serial cranial computed tomograms were carried out in 136 children with acute lymphoblastic leukaemia who were receiving $24 \mathrm{~Gy}$ or $18 \mathrm{~Gy}$ of cranial irradiation and continuing treatment with doses of methotrexate given weekly orally or intramuscularly. The findings were correlated with treatment variables, the development of fits, and the intelligence quotient (IQ). Reversible brain shrinkage, attributed to treatment with steroids, was found on 87 of 114 initial scans (76\%); 14 showed changes in white matter during treatment $(10 \%)$, and calcification was found in 13 either during or after treatment (10\%). Eight children $(6 \%)$ had fits, and in six of the eight there were changes in white matter or calcification on the scans. Comparison of the two radiotherapy dosages showed no difference in the incidence of abnormalities seen on computed tomography, fits, or serial IQ measurements, but children receiving intramuscular methotrexate had a higher incidence of calcification and a lower mean IQ at one year than those who received the drug orally, although this difference was not apparent later. Younger children were more likely to develop changes on computed tomograms and fits, and to have low IQs on completion of treatment, with changes most apparent in those less than 2 years of age. There were highly significant correlations between abnormalities on computed tomography, fits, and IQ. These findings confirm the neurological vulnerability of younger children with acute lymphoblastic leukaemia, show an association between abnormalities on computed tomography and intellectual deficit, and suggest that methotrexate is more toxic when given intramuscularly than orally. They provide no evidence that $18 \mathrm{~Gy}$ of cranial irradiation is less toxic than $24 \mathrm{~Gy}$, and indicate the need for alternative treatment regimens.
\end{abstract}

Hospital for

Sick Children,

Great Ormond Street,

London WC1N 3JH

J M Chessells

T C S Cox

B Kendall

N P C Cavanagh

L Jannoun

Clinical Trials Service

Unit, Oxford

S Richards

Correspondence to:

Dr Chessells.

Accepted 7 December 1989
Now that large numbers of children with acute lymphoblastic leukaemia are surviving for long periods, and many are cured, it has become apparent that an appreciable minority develop late effects of treatment. ${ }^{1}$ These include impaired growth and endocrine problems, ${ }^{1}$ and a range of neuropsychological disorders varying from subtle learning difficulties ${ }^{2}$ and abnormalities on computed tomography ${ }^{3}$ to overt neurological deterioration, dementia, and convulsions. ${ }^{4}$ Though such complications are, not surprisingly, more common among children who have received more than one course of treatment, ${ }^{1}$ their occurrence has lead to reappraisal of certain aspects of treatment, most notably that directed to the central nervous system (so called 'central nervous system prophylaxis'). The most commonly used central nervous system treatment has been a course of cranial irradiation in a dose of $24 \mathrm{~Gy}$, and intrathecal injections of methotrexate. At the same time a desire to decrease the rate of bone marrow relapse has lead to investigation of drug dosage and timing, particularly during continuing (maintenance) treatment. Our concern about the variability of absorption of methotrexate lead us to compare the oral and intramuscular routes of administration during continuing treatment of acute lymphoblastic leukaemia. We report here the results of investigations in a group of children with acute lymphoblastic leukaemia who received either $24 \mathrm{~Gy}$ or $18 \mathrm{~Gy}$ of central nervous system irradiation, and methotrexate given either orally or intramuscularly.

\section{Patients and methods}

Between 1979 and 1982, all children with non-T cell acute lymphoblastic leukaemia referred to this hospital were treated with a standard induction protocol comprising daunorubicin, vincristine, prednisolone and crisantaspase ( $\mathrm{L}$ asparaginase) and then, after treatment of the central nervous system was completed, continuing treatment with 6-mercaptopurine daily for two weeks in three, prednisolone and vincristine every six weeks, and methotrexate in a single weekly dose of $20 \mathrm{mg} / \mathrm{m}^{2}$. Children were randomly allocated to receive the methotrexate by mouth or as a single weekly intramuscular injection. This phase of treatment was continued for a total of 96 weeks. All children received treatment of the central nervous system which comprised methotrexate given intrathecally for six doses, and a course of cranial irradiation. Cranial irradiation was given for the first part of the trial in a dose of $24 \mathrm{~Gy}$ in 15 fractions over three weeks and, in January 1981, was reduced to $18 \mathrm{~Gy}$ in 10 fractions given over two weeks. Thus the allocation of the dose of radiotherapy, unlike the route of administration of the methotrexate, was not random.

Children who were under 2 years of age at the time of diagnosis received regular intrathecal injections of methotrexate every six weeks until their second birthday, when radiotherapy was given in a dose of $18 \mathrm{~Gy}$ in $\mathbf{1 0}$ fractions over two weeks. The details of this protocol have been published, ${ }^{5}$ and the design is shown in the figure. It was planned that children on this protocol should receive serial computed tomo- 
'PLOD' protocol for non-T, non-B acute lymphoblastic leukaemia. Numbers refer to doses of drug in $\mathrm{mg} / \mathrm{m}^{2} /$ surface area except for crisantaspase

(L-asparaginase), which is in units $/ \mathrm{m}^{2} /$ surface area.

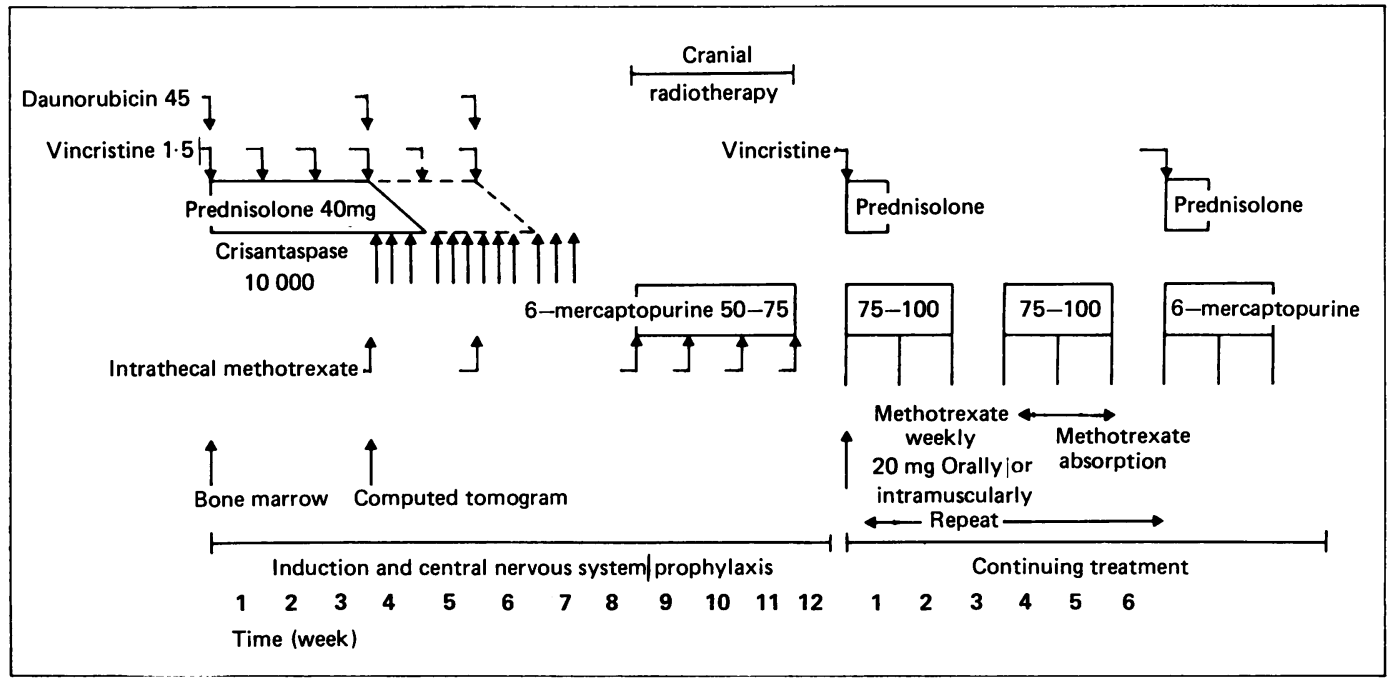

Table 1 Numbers of patients and investigations

\begin{tabular}{|c|c|c|c|c|c|c|c|}
\hline \multirow{2}{*}{$\begin{array}{l}\text { Age at diagnosis } \\
\text { (years) }\end{array}$} & \multirow{2}{*}{$\begin{array}{l}\text { Total } \\
\text { patients* }\end{array}$} & \multicolumn{2}{|c|}{ Route of methotrexate } & \multicolumn{2}{|c|}{ Cranial irradiation } & \multicolumn{2}{|c|}{$I Q$ assessment } \\
\hline & & Oral & Intramuscular & $24 G y$ & $18 G y$ & Serial & Late only \\
\hline $\begin{array}{l}<2 \\
2-5 \\
5-10 \\
10+\end{array}$ & $\begin{array}{rr}18 & (8) \\
65 & (39) \\
44 & (23) \\
9 & (4)\end{array}$ & $\begin{array}{c}13(6) \\
31(22) \\
24(11) \\
3(1)\end{array}$ & $\begin{array}{r}5(2) \\
34(17) \\
20(12) \\
6 \quad(3)\end{array}$ & $\begin{array}{l}\text { Deferred } \\
25(16) \\
19(9) \\
4(1)\end{array}$ & $\begin{array}{r}40(23) \\
25(14) \\
5 \quad(3)\end{array}$ & $\begin{array}{r}0 \\
27 \\
28 \\
5\end{array}$ & $\begin{array}{r}11 \\
23 \\
10 \\
1\end{array}$ \\
\hline Total & 136 & 71 & 65 & 48 & 70 & 60 & 45 \\
\hline
\end{tabular}

${ }^{*}$ Number of boys in parentheses.

graphy, psychological assessment, and neurological examination. The numbers of children in whom each of these investigations was carried out is shown in table 1 .

Whenever possible all patients had a computed tomogram within a week of diagnosis and again at one year, two years, and (when possible) between four and five years from diagnosis. Routine scans were performed with sedation where necessary using an EMI 1010 head scanner or Toshiba-60 without intravenous contrast. The scans were assessed by two observers (TCSC and BK) who had no knowledge of the clinical variables. A grading system was used to determine the degree of brain shrinkage (ventricular dilatation or wide superficial subarachnoid spaces) changes in white matter, or calcification; the presence of any abnormality was noted.

The numerical grading system was devised by comparison with normal control scans. An attempt was thus made to determine whether any of the changes noted were progressive. Progression was defined as an increase in the numerical grading score seen on two or more consecutive scans. The serial scans for each patient were assessed together.

Patients had psychological assessments before radiotherapy and at one and two years (and later) follow up when possible. Assessment included measures of general intelligence (IQ) using the revised Wechsler intelligence scale for children for those over the age of 6 years. ${ }^{6}$ The McCarthy scales of children's abilities, ${ }^{7}$ and the British ability scales, ${ }^{8}$ were used for children under the age of 6 years. The attainments of children of school age were assessed with the British ability scales. Assessment of all children was not possible for logistic reasons, and some children, together with those aged less than 2 at diagnosis, had a single IQ test on completion of treatment.

The patients were seen by a paediatric neurologist within six months of completion of treatment, or sooner in the event of overt neurological problems. A history was taken of the pregnancy and delivery, birth weight, developmental milestones, and of previous illnesses. Details of the family history were recorded. A history was also taken of any symptoms during the treatment: weakness, unsteadiness, headaches, or visual disturbance. Information about any fits, their nature and frequency, were also recorded.

The child was given a neurological examination and a record was made of clumsiness (dyspraxia) and joint mobility. Head circumference and visual acuity were recorded and a note was made of whether the child was left or right handed.

The overall design of the trial, and the pharmacokinetics of methotrexate, have been reported in detail elsewhere. At the time of the first report there was no significant difference in event free survival between children receiving methotrexate orally or intramuscularly. The data were analysed again in December 1988 (minimum follow up for all patients of six years) and there remains no difference in survival between the children in the two treatment groups. Children who relapsed were withdrawn from the study, but results of investigations carried out before relapse are included.

The associations between variables (such as abnormalities on computed tomograms, fits, and treatment regimens) were tested by $\chi^{2}$ 
analysis. Because of the association between abnormalities and age, comparisons of treatments were adjusted for age by calculating the difference between observed and expected findings and its variance, and summing over the age group. ${ }^{9}$ Any differences in mean IQ between treatment groups at two years and between those with and without abnormalities on computed tomography were assessed by Student's $t$ test.

A $\chi^{2}$ test for trend was used to see if there were any trends towards more abnormalities at younger ages, and one way analysis of variance was used to see if there was any association between IQ two years after diagnosis and age.

The number of patients who had IQ tests both at diagnosis and later was quite small, so to look for any effect of treatment on serial IQ, the Mann-Whitney test was used to compare the apparent percentage increases in IQ from diagnosis to one year, and from diagnosis to two years, between treatment groups. This allows for the non-normal distribution of the percentage increases. Most analyses were performed using the statistical software package BMDP. ${ }^{10}$

Permission for the study and accompanying investigations was given by the joint ethics committee of the Hospital for Sick Children and Institute of Child Health.

\section{Results}

One hundred and sixty four children were entered into the study, of whom 158 achieved remission. Three children with Down's syndrome and one whose mother had Down's syndrome were excluded from the study, together with one infant (the only patient in the series) in whom central nervous system disease was present at the time of first lumbar puncture. Seventeen patients were not available for computed tomography either because the parents did not consent to the investigation or they lived too far away, and thus this report concerns the remaining 136 (table 1). The patients are divided by age: under 2 years, 2 to 5,5 to 10 , and over 10 years. The numbers of investigations performed in each group are given.

CHILDREN UNDER 2 YEARS

Eighteen children were under 2 years old at the time of diagnosis, five of whom received intramuscular and 13 oral methotrexate. Fifteen of 17 scans carried out on children within the first three weeks of presentation showed brain shrinkage, but this was not progressive in any of the 14 who had follow up scans. Change in white matter was found in four of the 14 children scanned again at one year or subsequently, and calcification in three of 14. Changes in white matter detected at two years were not detected on later follow up in three children, but calcification was equally prominent in two of the three children with previous changes who were scanned again at five years. The full scale IQ obtained after completion of treatment in 11 children ranged from 61 to 124 (mean 90), but only one child in the series had an IQ of more than 100, and only three had IQs between 90 and 100 . One child, with a coexistent left sided arachnoid cyst on computed tomography, had had fits before the onset of treatment, and three others had fits during or after treatment. Of the 11 children who had neurological examinations on completion of treatment, one showed some clumsiness, three had exaggerated knee reflexes, and five had hypermobility of their joints.

\section{CHILDREN AGED 2 TO 5 (table 2)}

There were 65 children in this group; 51 had some brain shrinkage on at least one scan, 43 on the first. Two had progressive brain shrinkage. Change in white matter during the first two years was detected in seven children, but did not progress on subsequent scans. At longer follow up, change in white matter was only detectable in one child. Calcification, however, was noted in five children during the first two years, and a further four at four to five years' follow up. Full scale IQ gave a mean value of 109 at one year, 107.6 at two years, and 118 at four to five years. Four of the children in this age group had had one or more fits associated with fever before the start of treatment; none of these developed fits during or after treatment. Five additional children had fits during or after treatment, four of whom were receiving methotrexate intramuscularly. Neurological examination of 46 children showed that 14 were clumsy, 11 had exaggerated knee reflexes, and 26 had hyperextensible joints.

CHILDREN OVER 5 YEARS OF AGE (table 3) As there were only nine children in the study who were over 10 years of age at the time of diagnosis, the findings of those who were over 5 and those who were over 10 are shown in table 3. There were 44 children below 10 , and nine over 10. Brain shrinkage was noted in 29 of 43 at the beginning of treatment but did not progress in any of them. Change in white matter was detected in two during the first two years

Table 2 Results of computed tomography and IQ testing in children aged 2-5 years

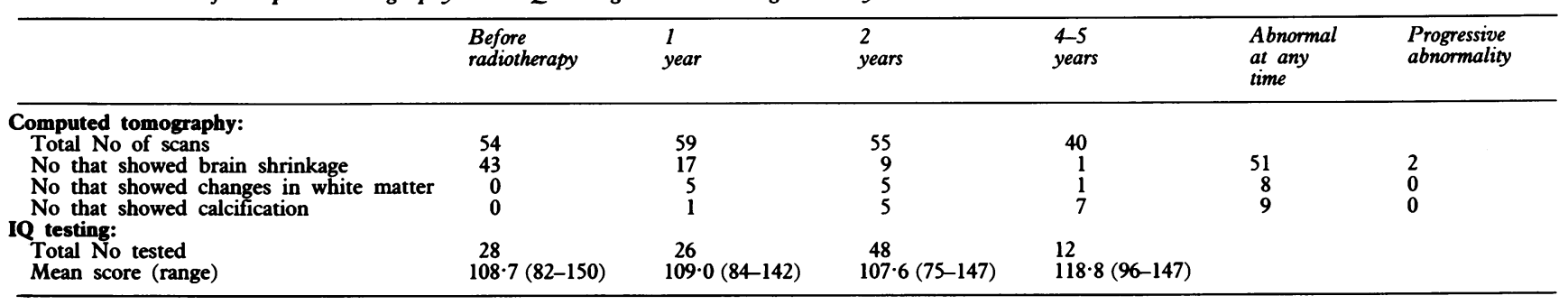


Table 3 Results of computed tomography and IQ testing in children aged over 5 years

\begin{tabular}{|c|c|c|c|c|c|c|}
\hline & $\begin{array}{l}\text { Before } \\
\text { radiotherapy }\end{array}$ & $\begin{array}{l}1 \\
\text { year }\end{array}$ & $\begin{array}{l}2 \\
\text { years }\end{array}$ & $\begin{array}{l}4-5 \\
\text { years }\end{array}$ & $\begin{array}{l}\text { Abnormal } \\
\text { at any } \\
\text { time }\end{array}$ & $\begin{array}{l}\text { Progressive } \\
\text { abnormality }\end{array}$ \\
\hline $\begin{array}{l}\text { Computed tomography: } \\
\text { Total No of scans } \\
\text { No that showed brain shrinkage } \\
\text { No that showed changes in white matter } \\
\text { No that showed calcification } \\
\text { IQ testing: }\end{array}$ & $\begin{array}{r}43 \\
29 \\
0 \\
0\end{array}$ & $\begin{array}{r}47 \\
19 \\
2 \\
0\end{array}$ & $\begin{array}{r}41 \\
17 \\
2 \\
1\end{array}$ & $\begin{array}{r}24 \\
2 \\
0 \\
1\end{array}$ & $\begin{array}{r}36 \\
2 \\
1\end{array}$ & $\begin{array}{l}0 \\
0 \\
0\end{array}$ \\
\hline $\begin{array}{l}\text { Total No tested } \\
\text { Mean score (range) }\end{array}$ & $\begin{array}{l}38 \\
113 \cdot 9(84-144)\end{array}$ & $\begin{array}{l}33 \\
114 \cdot 8(81-138)\end{array}$ & $\begin{array}{l}41 \\
112 \cdot 9(61-142)\end{array}$ & $115 \cdot 8(95-136)$ & & \\
\hline
\end{tabular}

but not later in any patient. Calcification was found in one child, but no child had progressive calcification or change in white matter. Calcification and change in white matter were only seen in children who received methotrexate intramuscularly. The mean IQ at diagnosis was 113.9 , at two years 112.9 , and at long term follow up $115 \cdot 8$. Thirteen of 51 children examined on completion of treatment were clumsy, 16 had exaggerated knee reflexes, and 10 had hyperextensible joints. Three children in this age group had had one or more fits before treatment in association with fever, but no child developed convulsions during or after treatment, and no other child in this age group subsequently developed convulsions.

\section{OVERT NEUROLOGICAL ABNORMALITIES}

Eight children had histories of one or more fits before treatment. In seven (all aged under 6 at the time of diagnosis) the fits seemed to have occurred in association with fever. The eighth child is discussed below. None of these children seemed susceptible to fits during treatment. Eight additional children developed fits during or after treatment of whom two had no abnormalities on computed tomography. The other six developed convulsions during or after treatment, and the scan showed change in white matter or calcification. In three of these there was obvious simultaneous neurological deterioration. Further details on these children are given in table 4 . All were aged under 5 at the time of diagnosis but only one was under 2; five were receiving methotrexate intramuscularly. One child (case 6) developed an acute encephalopathy that was presumed to be viral, and at necropsy measles encephalitis was found. In no other child was a viral cause found for neurological problems.
Two children (cases 4 and 5) developed progressive convulsions with calcification and changes in white matter. Both were receiving methotrexate intramuscularly, and both subsequently relapsed, one receiving further methotrexate. At subsequent follow up there was neurological deterioration and persisting fits. Both were thought clinically to have methotrexate leucoencephalopathy but unfortunately permission for necropsy was not obtained for either. Three children survived, one (case 2), the only one in the series who received methotrexate orally, is well with prominent calcification on scan; his fits have stopped but he has a full scale IQ of 79 and requires remedial help at school. Case 1, who was 14 months old at the time of diagnosis and received methotrexate intramuscularly and long term methotrexate intrathecally, is also well but has an IQ of 61 and severe learning problems. Case 2 has had severe grand mal convulsions that started after completion of treatment, and calcification was first noted on her scan five years after diagnosis. She has appreciable learning problems, an IQ of 79 , and became pubertal at the age of $8 \cdot 2$ years. One additional infant (case 7 who was described previously) was found to have an arachnoid cyst; he subsequently relapsed and died. The two year scan of one further child (not mentioned in the table) is suggestive of an infarct, but the child is well and free of symptoms, has no learning problems, and an IQ of 124.

\section{ANALYSIS OF IQ}

At the time of diagnosis the mean IQ of the whole sample was within the normal high average range of intelligence and the distribution of values was normal. Table 5 shows the mean (SD) IQs of the two radiotherapy and methotrexate groups for those patients who had tests

Table 4 Clinical details of children with fits and abnormal computed tomograms

\begin{tabular}{|c|c|c|c|c|c|}
\hline $\begin{array}{l}\text { Case } \\
\text { No }\end{array}$ & $\begin{array}{l}\text { Age at } \\
\text { diagnosis } \\
\text { (years) }\end{array}$ & $\begin{array}{l}\text { Route by } \\
\text { which } \\
\text { methotrexate } \\
\text { given }\end{array}$ & Radiotherapy & $\begin{array}{l}\text { Findings on } \\
\text { computed tomography }\end{array}$ & Complications \\
\hline 1 & $1 \cdot 1$ & Intramuscular & $\begin{array}{l}\text { Deferred } \\
20 \mathrm{~Gy}\end{array}$ & $\begin{array}{l}\text { Atrophy, white matter } \\
\text { change, calcification }\end{array}$ & Fits; IQ 61 \\
\hline 2 & $2 \cdot 0$ & Oral & 18 Gy & $\begin{array}{l}\text { Persistent calcification; } \\
\text { change in white matter after } \\
\text { one year of treatment }\end{array}$ & Fits; IQ 79 \\
\hline 3 & $2 \cdot 0$ & Intramuscular & $24 \mathrm{~Gy}$ & Late (4 years) calcification & $\begin{array}{l}\text { Grand mal fits; an episode of } \\
\text { hemiplegia; early puberty; IQ } 75\end{array}$ \\
\hline 4 & $4 \cdot 0$ & Intramuscular & 24 Gy & $\begin{array}{l}\text { Atrophy, white matter } \\
\text { change }\end{array}$ & $\begin{array}{l}\text { Persistent fits; progressive } \\
\text { abnormality on computed } \\
\text { tomography; died in relapse }\end{array}$ \\
\hline 5 & $3 \cdot 3$ & Intramuscular & $24 \mathrm{~Gy}$ & $\begin{array}{l}\text { Atrophy, white matter } \\
\text { change, calcification }\end{array}$ & $\begin{array}{l}\text { Relapse; further methotrexate } \\
\text { given; died }\end{array}$ \\
\hline 6 & $3 \cdot 0$ & Intramuscular & 24 Gy & $\begin{array}{l}\text { Calcification, white matter } \\
\text { change }\end{array}$ & $\begin{array}{l}\text { Progressive central nervous system } \\
\text { deterioration and fits; measles }\end{array}$ \\
\hline 7 & $1 \cdot 0$ & Oral & Deferred & $\begin{array}{l}\text { Subarachnoid cyst left } \\
\text { temporal region }\end{array}$ & $\begin{array}{l}\text { Fits before treatment; relapse at } \\
\text { two years }\end{array}$ \\
\hline
\end{tabular}


Table 5 Average IQ at diagnosis and during follow up according to dose of radiotherapy and route by which methotrexate given

\begin{tabular}{|c|c|c|c|c|c|c|}
\hline & \multicolumn{2}{|c|}{ At diagnosis } & \multicolumn{2}{|c|}{ At 1 year } & \multicolumn{2}{|c|}{ At 2 years } \\
\hline & $\begin{array}{l}\text { No } \\
\text { tested }\end{array}$ & $\begin{array}{l}\text { Mean }(S D) \\
I Q\end{array}$ & $\begin{array}{l}\text { No } \\
\text { tested }\end{array}$ & $\begin{array}{l}\text { Mean }(S D) \\
I Q\end{array}$ & $\begin{array}{l}\text { No } \\
\text { tested }\end{array}$ & $\begin{array}{l}\text { Mean }(S D) \\
I Q\end{array}$ \\
\hline $\begin{array}{l}\text { Radiotherapy: } 24 \mathrm{~Gy} \\
\text { Radiotherapy: } 18 \mathrm{~Gy} \\
\text { Methotrexate: oral } \\
\text { Methotrexate: intramuscular }\end{array}$ & $\begin{array}{l}21 \\
33 \\
26 \\
28\end{array}$ & $\begin{array}{l}116 \cdot 0(12 \cdot 7) \\
111 \cdot 5(16 \cdot 4) \\
115 \cdot 2(15 \cdot 5) \\
111.4(14 \cdot 8)\end{array}$ & $\begin{array}{l}21 \\
33 \\
26 \\
28\end{array}$ & $\begin{array}{l}115 \cdot 9(13 \cdot 6) \\
111 \cdot 2(15 \cdot 9) \\
117 \cdot 2(14 \cdot 3) \\
109 \cdot 1(14 \cdot 9)\end{array}$ & $\begin{array}{l}21 \\
33 \\
26 \\
28\end{array}$ & $\begin{array}{l}115 \cdot 7(15 \cdot 4) \\
113 \cdot 6(15 \cdot 2) \\
118 \cdot 5(16 \cdot 2) \\
110 \cdot 6(13 \cdot 4)\end{array}$ \\
\hline
\end{tabular}

at the time of diagnosis, and at one and two years.

Whereas there was an apparent slight increase in the mean IQs of children receiving methotrexate orally, those of children receiving methotrexate intramuscularly showed an apparent decrease. Analysis of variance showed no significant difference between these results. Estimation of the percentage increase in IQ from presentation to one year using the MannWhitney (non-parametric) test, showed a significant difference between the children receiving methotrexate orally and intramuscularly, but this difference was not sustained when the values at presentation and at two years were compared. There were no significant differences between the two radiotherapy groups.

\section{RISK FACTORS FOR DEVELOPMENT OF} ABNORMALITIES

There was no association between age at the time of diagnosis and the appearance of brain shrinkage on computed tomography, but younger children were significantly more likely to develop changes in white matter $(p<0.025)$, calcification, $(p<0.025)$, fits $(p<0.01)$, and hyperextensible joints $(p<0.01)$ than older children; they were not, however, more likely to be clumsy. The IQ on completion of treatment was significantly lower $(p=0.0006)$ in the under 2 year olds, and a regression analysis of IQ and age showed a significant correlation $(\mathrm{p}=0 \cdot 01)$.

There was no association between any of the findings on computed tomography or any neurological abnormality, and the sex of the child.

Children who received $24 \mathrm{~Gy}$ of irradiation were at no more risk of abnormalities visible on scans than those receiving $18 \mathrm{~Gy}$ (table 6). Table 6 also shows the influence of route of administration of the methotrexate. Although more children who received methotrexate intramuscularly developed change in white matter $(9 / 65$ compared with $5 / 71$ ), this difference was not significant, nor was the difference in the incidence of fits, but calcification was found more often in those receiving methotrexate intramuscularly $(p=0.03)$. This significance disappeared when allowance was made for age.

INTER-RELATIONSHIP OF ABNORMALITIES (table 7) There was no relationship between the presence of brain shrinkage on computed tomography and the development of fits or the assessment of IQ. There seemed to be an association between clumsiness on neurological follow up examination and the presence of atrophy on the final follow up scan. Children with change in white matter or calcification seen on the scan were significantly more likely to have fits, but there was no association between these findings and any other neurological symptoms. There was a highly significant correlation between the occurrence of fits during or after treatment and the IQ, and between these findings and changes on computed tomography.

PROBLEMS OF GROWTH AND DEVELOPMENT Prospective assessment of endocrine function

Table 6 Results according to dose of radiotherapy and route of administration of methotrexate

\begin{tabular}{|c|c|c|c|c|}
\hline & \multicolumn{2}{|c|}{$\begin{array}{l}\text { Dose of } \\
\text { radiotherapy* }\end{array}$} & \multicolumn{2}{|c|}{$\begin{array}{l}\text { Route of administration } \\
\text { of methotrexate }\end{array}$} \\
\hline & $24 G y$ & $18 G y$ & Oral & Intramuscular \\
\hline $\begin{array}{l}\text { Total No } \\
\text { Abnormalities on computed tomography: }\end{array}$ & 48 & 70 & 71 & 65 \\
\hline $\begin{array}{l}\text { No that showed brain shrinkage } \\
\text { No that showed changes in white matter } \\
\text { No that showed calcification } \\
\text { No that developed fits } \\
\text { IO at two years: }\end{array}$ & $\begin{array}{r}33 \\
3 \\
3 \\
4\end{array}$ & $\begin{array}{r}54 \\
7 \\
7 \\
1\end{array}$ & $\begin{array}{r}53 \\
5 \\
3 \\
2\end{array}$ & $\begin{array}{r}49 \\
9 \\
10 \\
6\end{array}$ \\
\hline $\begin{array}{l}\text { No tested } \\
\text { Mean IQ }\end{array}$ & $\begin{array}{r}31 \\
110\end{array}$ & $\begin{array}{c}59 \\
109 \cdot 4\end{array}$ & $\begin{array}{c}52 \\
109 \cdot 1\end{array}$ & $\begin{array}{l}48 \\
105 \cdot 5\end{array}$ \\
\hline
\end{tabular}

${ }^{*}$ Children aged $<2$ years were excluded.

Table 7 Inter-relationship of abnormalities

\begin{tabular}{|c|c|c|c|c|}
\hline & \multicolumn{3}{|c|}{ Abnormalities on computed tomography } & \multirow{2}{*}{ Fits } \\
\hline & $\begin{array}{l}\text { Brain } \\
\text { shrinkage }\end{array}$ & $\begin{array}{l}\text { Changes in } \\
\text { white matter }\end{array}$ & Calcification & \\
\hline $\begin{array}{l}\text { Fits } \\
\text { Low IQ } \\
\text { Headache } \\
\text { Clumsiness } \\
\text { Hyperextensibility of joints } \\
\text { Exaggerated reflexes }\end{array}$ & $\begin{array}{l}\text { NS } \\
\text { NS } \\
\text { NS } \\
0 \cdot 05 \\
\text { NS } \\
\text { NS }\end{array}$ & $\begin{array}{l}0.0001 \\
0.03 \\
\text { NS } \\
\text { NS } \\
\text { NS } \\
\text { NS }\end{array}$ & $\begin{array}{l}<0.0005 \\
0.0001 \\
\text { NS } \\
\text { NS } \\
\text { NS } \\
\text { NS }\end{array}$ & $\begin{array}{l}\text { Not applicable } \\
<0 \cdot 0005 \\
\text { NS } \\
\text { NS } \\
\text { NS } \\
\text { NS }\end{array}$ \\
\hline
\end{tabular}


was not a part of this study. The youngest children have now reached the age of 9-10 years, and precocious or early puberty has been noted in nine girls and premature adrenarche in one boy. There is no association between the dose of cranial irradiation or the route of administration of methotrexate, and the onset of early puberty. Assessment of growth hormone was not undertaken, but one additional boy has declined further investigation and has clinical growth hormone deficiency.

\section{Discussion}

A wide range of neuropsychological problems occur in children who are treated for acute lymphoblastic leukaemia. These include learning difficulties and low or declining IQ scores, ${ }^{2} 11$ usually more pronounced in younger children, ${ }^{12}$ and even neurological deterioration, dementia, and necrotising leucoencephalopathy. ${ }^{4}$ Though leucoencephalopathy has most frequently been reported in children treated for one or more episodes of leukaemia of the central nervous system, usually with radiation and prolonged intrathecal chemotherapy, ${ }^{13}$ it has also been described in children in first remission who have received methotrexate intrathecally together with cranial irradiation, and subsequent methotrexate given intravenously. ${ }^{14} 15$ Computed tomography of the brain in methotrexate radiation encephalopathy has been well described, and abnormalities include ventricular and subarachnoid dilatation, low attenuation of white matter, and intracerebral calcification. ${ }^{16}$ Similar changes may be found, however, in children without symptoms who are treated for acute lymphoblastic leukaemia, although the incidence of such change varies and may well be associated with the type of central nervous system treatment. It has been reported that computed tomographic changes such as calcification and cortical atrophy show strong correlation with the extent of intellectual impairment. ${ }^{17}$ Seizures, though a feature of methotrexate encephalopathy, also occur in up to $10 \%$ of children with acute lymphoblastic leukaemia and may be more common in those receiving the drug intrathecally and intravenously than in those receiving cranial irradiation and short term methotrexate intrathecally. ${ }^{18}$

Clearly there is no single cause of these problems, and it has even been argued that many, if not all of the learning problems may be attributed to the effects of leukaemia itself or those of chronic illness, rather than to treatment directed at the central nervous system. ${ }^{19}$ Prospective psychometric studies are hampered by the young age of many of the patients and the high attrition rate of the disease. A recent metaanalysis of most papers published on the subject, however, has concluded that most, if not all, of the problems are the result of the treatment rather than the disease. ${ }^{20}$

The three main therapeutic components predisposing to central nervous system damage in children treated for acute lymphoblastic leukaemia have been identified as cranial irradiation, methotrexate given intravenously, and methotrexate given intrathecally. ${ }^{4}$ Analysis of their individual contribution to damage is difficult, because all three treatments are frequently given in conjunction.

These concerns have lead to reappraisal and modification of treatment directed at the central nervous system but such changes must be tempered by the realisation that all children with acute lymphoblastic leukaemia are at some risk of central nervous system relapse, and that the outcome after overt central nervous system leukaemia is poor. ${ }^{21}$

Regular intrathecal chemotherapy without cranial irradiation may be adequate for some patients, ${ }^{22}$ and there is some retrospective evidence that it is less damaging, ${ }^{23} 24$ but patients receiving regular methotrexate intrathecally and intravenously have been reported as showing more abnormalities on computed tomography and similar IQ scores when compared with those receiving short term treatment intrathecally together with cranial irradiation. ${ }^{25} 26$

Our decision to reduce the dose of cranial irradiation during the study was prompted by these concerns and by the report from the American Children's Cancer Study Group that a dose of $18 \mathrm{~Gy}$ was as effective as $24 \mathrm{~Gy}$ in treatment of the central nervous system, ${ }^{27}$ and we hoped that it would prove less toxic. Similarly, by deferring irradiation in children under 2 years old, we hoped to reduce the problems in young children. The randomised comparison of methotrexate given orally and intramuscularly was undertaken with knowledge of the variable concentrations obtained after oral treatment, ${ }^{28}$ confirmed by us during this work, ${ }^{29}$ and in the hope that methotrexate given intramuscularly would decrease the bone marrow and testicular relapse rate. The work reported here was planned prospectively to monitor any potential toxicity. We had calculated that the dose of methotrexate of $20 \mathrm{mg} / \mathrm{m}^{2}$ needed for intramuscular use was much lower than that of $40-60 \mathrm{mg}$ that was reported to cause neurological dysfunction. ${ }^{14} 15$

Our results, however, show that there was no difference in the incidence of abnormalities on computed tomography, fits, or changes in IQs, in the two groups of children who received either 18 or $24 \mathrm{~Gy}$. Moreover, as we have previously reported, the incidence of precocious puberty, and thus presumably pituitary-hypothalamic dysfunction, remains similar. ${ }^{30}$ Thus we have no evidence to suggest that the lower dose of irradiation is less toxic.

By contrast, we found some evidence that methotrexate given intramuscularly was more toxic than when given orally; more children receiving the drug intramuscularly developed attenuation of white matter and fits during or after treatment in association with abnormalities on scans. These results were not significant, but they are suggestive, particularly in view of the additional finding of increased calcification in the group receiving the drug intramuscularly. There was also some evidence that IQ measurements declined in children receiving methotrexate intramuscularly, although this finding was not sustained on longer follow up. Four of the five children who developed repeated fits in 
association with abnormalities on their scans were receiving methotrexate intramuscularly. Though all three of the five who survived have serious learning problems, none has the focal neurological abnormality or continued deterioration described in gross encephalopathy associated with higher dose methotrexate given intravenously.

Our analysis of the risk factors for neuropsychological damage in this study confirms once again the vulnerability of young children, but not that of girls that has been reported by others. ${ }^{31}$ In retrospect, our decision to defer irradiation in those under 2 years old possibly contributed to these results, as these children received prolonged intrathecal chemotherapy as well as irradiation. New regimens for this age group are clearly indicated.

Our results also show that younger children are also more likely to develop abnormalities on computed tomography. It is difficult to compare our incidence of abnormalities with those reported by others because the details of treatment vary; for example, one of the highest rates of abnormalities has been reported in children receiving cranial irradiation and monthly intrathecal chemotherapy. ${ }^{3}$ The high incidence of brain shrinkage we noted on the initial scans reflected treatment with steroids and was presumably reversible damage. The incidence of long term atrophy was much lower. We noted, like others, ${ }^{25}$ that the appearance of attenuation of white matter did not necessarily persist in follow up scans; this abnormality would have been more effectively assessed by nuclear magnetic resonance. ${ }^{32}$

Calcification, in contrast to change in white matter, may not develop for some years after the start of treatment, ${ }^{33}$ and several of our patients showed this late change. There was a highly significant correlation between the IQ and the presence of calcification or attentuation of white matter on scan, a relationship also noted in a group of 23 children in a previous study. ${ }^{17} \mathrm{We}$ have thus shown that in a group of children receiving treatment for acute lymphoblastic leukaemia, abnormalities of computed tomography, fits, and a low IQ all tend to occur in association; that younger children are more vulnerable to all of these problems; and that vulnerability may be exacerbated by the use of moderate intramuscular doses of methotrexate. Neuropsychological problems were not ameliorated by the reduction of cranial irradiation from 24 to $18 \mathrm{~Gy}$, or by deferring radiotherapy in the younger children. These results highlight the need for effective alternative treatment of the central nervous system, particularly in the younger child, but attempts to evaluate such alternatives should be accompanied by prospective neuropsychological assessment.

We thank Miss J Stevens for her dedication and enthusiasm, and the Medical Research Council and the Leukaemia Research Fund for financial support.

1 Wheeler K, Leiper AD, Jannoun L, Chessells JM. Medical cost of curing childhood acute lymphoblastic leukaemia. $\mathrm{Br}$ Med f 1988;296:162-6.

2 Jannoun L, Chessells JM. Long-term psychological effects of childhood leukaemia and its treatment. Pediatric Hematology and Oncology 1987;4:293-308.

3 Peyland Ramu N, Poplack DG, Pizzo PA, Adornato BT, Di Chiro G. Abnormal CT scans of the brain in asymptomatic children with acute lymphocytic leukemia after prophylactic treatment of the central nervous system with radiation and intrathecal chemotherapy. $N$ Engl f Med 1978;298:815-8.

4 Bleyer WA. Neurologic sequelae and ionizing radiation: a new classification. Cancer Treat Rep 1981;65:89-98.

5 Chessells JM, Leiper AD, Tiedemann K, Hardisty RM, Richards S. Oral methotrexate is as effective as intramuscular in maintenance therapy of acute lymphoblastic leukaemia. Arch Dis Child 1987;62:172-6.

6 Wechsler D. Wechsler intelligence scale for children. Revised manual. New York: Psychological Corporation, 1974.

7 McCarthy D. McCarthy scales of children's abilities manual. New York: Psychological Corporation, 1970.

8 Elliott C, Murray D, Pearson L. Manual for the British ability scales. Windsor: NFER Publishing Co, 1978.

9 Yusuf S, Peto R, Lewis J, Collins R, Sleight P. Beta blockade during and after myocardial infarction: overview of the randomized trials. Prog Cardiovasc Dis 1985;27:335-71.

0 Dixon WJ. BDMP statistical software. Los Angeles: BDMP Statistical Software Inc, 1985.

11 Meadows TA, Massari DJ, Ferguson J, Gordon J, Littman P, Moss K. Declines in IQ scores and cognitive dysfunction in children with acute lymphocytic leukaemia treated with cranial irradiation. Lancet 1981;ii:1015-8.

12 Jannoun $L$. Are cognitive and educational development affected by age at which prophylactic therapy is given in acute lymphoblastic leukaemia? Arch Dis Child 1983;58: 953-8.

13 Rubinstein LJ, Herman MM, Long TF, Wilbur JR. Disseminated necrotizing leukoencephalopathy: a complication of treated central nervous system leukemia and lymphoma. Cancer 1975;35:291-305.

14 McIntosh S, Klatskin EH, O'Brien RT, et al. Chronic neurologic disturbance in childhood leukaemia. Cancer 1976;37:853-7.

15 Ch'ien LT, Aur RHA, Verzosa MS, et al. Progression of methotrexate-induced leukoencephalopathy in children methotrexate-induced leukoencephalopathy in chill

16 Peylan-Ramu N, Poplack DG, Blei CL, Herdt JR, Vermess M, Di Chiro G. Computer assisted tomography in methotrexate encephalopathy. $\mathcal{F}$ Comput Assist Tomogr 1977;1: trexate

17 Brouwers P, Riccardi R, Fedio P, Poplack DG. Long-term neuropsychologic sequelae of childhood leukaemia: correlation with CT brain scan abnormalities. $\mathcal{f}$ Pediatr 1985 106:723-8.

18 Ochs J, Bowman WP, Pui C-H, Abromowitch MA, Mason C Simone JV. Seizures in childhood lymphoblastic leukaemi patients. Lancet 1984; ii: 1422-4.

19 Williams JM, Davis KS. Central nervous system prophylactic treatment for childhood leukaemia: neuropsyhological outcome studies. Cancer Treat Rev 1986;13:113-27.

20 Cousens P, Waters B, Said J, Stevens M. Cognitive effects of cranial irradiation in leukaemia: a survey and metacranial irradiation in leukaemia: a survey and

21 Pinkerton CR, Chessells JM. Failed CNS prophylaxis in childhood ALL. Br 7 Haematol 1984;57:553-61.

22 Littman P, Coccia P, Bleyer WA, et al. Central nervous system (CNS) prophylaxis in children with low risk acute lymphoblastic leukaemia (ALL). Int Y Radiat Oncol Biol Phys 1987;13:1443-9.

23 Pfefferbaum-Levine B, Copeland DR, Fletcher JM, Ried HL, Jaffe N, McKinnon WR. Neuropsychologic assessment of long-term survivors of childhood leukemia. $A m \mathcal{J}$ Pediatr Hematol Oncol 1984;6:123-7.

24 Rowland JH, Glidewell OJ, Sibley RF, et al. Effects of different forms of central nervous system prophylaxis on neuropsychologic function in childhood leukemia. $7 \mathrm{Clin}$ Oncol 1984;2:1327-35.

25 Ochs JJ, Parvey LS, Whitaker JN, et al. Serial cranial computed-tomography scans in children with leukemia given two different forms of central nervous system therapy. F Clin Oncol 1983;1:793-8.

26 Mulhern RK, Wasserman AL, Fairclough D, Ochs JJ Memory function in disease-free survivors of childhood acute lymphocytic leukaemia given CNS prophylaxis with acute lymphocytic leukaemia given CNS prophylaxis with
or without 1800 cGy cranial irradiation. $\mathscr{f}$ Clin Oncol or without 1800

27 Nesbit ME, Robison LL, Littman PS, et al. Presymptomatic central nervous system therapy in previously untreated childhood acute lymphoblastic leukaemia: comparison of $1800 \mathrm{rad}$ and $2400 \mathrm{rad}$. Lancet 1981 ;ii:461-6.

28 Balis FM, Savitch JL, Bleyer WA. Pharmacokinetics of oral methotrexate in children. Cancer Res 1983;43:2342-5.

29 Pearson ADJ, Mills S, Amineddine HA, Long DR, Craf AW, Chessells JM. Pharmacokinetics of oral and intramuscular methotrexate in children with acute lymphoblastic leukaemia. Cancer Chemother Pharmacol 1987;20 243-7.

30 Leiper AD, Stanhope R, Kitching P, Chessells JM. Precocious and premature puberty associated with the treatment of acute lymphoblastic leukaemia. Arch Dis Child 1987;62:1107-12.

31 Robison LL, Nesbit ME, Sather HN, Meadows AT, Ortega JA, Hammond GD. Factors associated with IQ scores in longterm survivors of childhood acute lymphoblastic leukaemia. Am J Pediatr Hematol Oncol 1984;6:115-21.

32 Packer RJ, Zimmerman RA, Bilaniuk LT. Magnetic resonance imaging in the evaluation of treatment related central nervous system damage. Cancer 1986;58:635-40.

33 Riccardi R, Brouwers P, DiC Chiro G, Poplack DG. Abnormal computed tomography brain scans in children Abnormal computed tomography brain scans in children
with acute lymphoblastic leukaemia: serial long-term follow up. F Clin Oncol 1985;3:12-8. 